\title{
Removing Boundaries, Losing Connections: Electoral Consequences of Local Government Reform in Japan
}

\author{
Yusaku Horiuchi, Jun Saito, and Kyohei Yamada
}

In this article we examine the role of local politicians in affecting national-level election outcomes by focusing on the drastic municipal mergers in Japan that took place in the early 2000s. Specifically, we argue that the political party that relies most extensively on local politicians' efforts for electoral mobilization and monitoring will suffer an electoral slump when municipalities are merged and the number of municipal politicians is swiftly reduced. We empirically show that municipalities with a history of mergers exhibit significantly lower voter turnout and obtain a smaller vote share for the ruling Liberal Democratic Party in national elections when compared to other municipalities without an experience of mergers. This result indicates that municipal politicians are indispensable human resources for LDP candidates running for the national parliament. KEYWORDS: municipal merger, decentralization, election, LDP, Japan

MUNICIPAL GOVERNMENTS ARE THE SMALLEST AND MOST BASIC UNIT OF representative democracy (Dahl and Tufte 1973, 13). Politicians serving in these governments-mayors and members of municipal assemblies-perform important functions in the policy process by meeting residents on a regular basis, discussing policy matters with them, and making policy decisions that affect the communities in which they reside. These municipal political elites not only are political actors in their own narrowly defined geographic jurisdictions, but they also constitute the cornerstones of national party organizations since they are the hubs of the community-based social and political network (Curtis 1992; Fenno 1978). More specifically, politicians seeking elective office at the national level rely on the 
mobilization efforts of the party activists at the grassroots level (Rosenstone and Hansen 1993). Additionally, existing studies on electoral politics suggest that municipal politicians may be key players for party headquarters because they monitor voters' electoral behavior and identify who should be rewarded or punished (Nichter 2008; Stokes 2005).

In this article, we examine the role of local politicians in affecting national-level election outcomes. In particular, by using empirical observations drawn from Japan, we investigate what would happen to election results for national legislatures if a large number of municipal-level activists were suddenly lost. We approach this counterfactual question by estimating the effects of drastic municipal government mergers in Japan, which reduced the total number of municipal legislators by over 30 percent within a short period of time in the early 2000s. In Japan, municipal politicians (i.e., mayors and members of municipal assemblies) are perceived as performing important functions in electoral machines. If these municipal politicians are indeed indispensable human resources for candidates running for the national parliament, we expect that decreasing the number of municipal politicians would affect voters' decisions of whether to vote and for whom to cast their ballots. On the contrary, if the activities of municipal political elites are irrelevant to national elections, their abrupt disappearance due to local government restructuring should not significantly affect the results of parliamentary elections.

Japan's recent experience of drastic municipal mergers provides an interesting opportunity to ponder this question. In Japan, the number of municipalities sharply and abruptly declined from 3,252 in January 2000 to 1,847 in April 2006. More importantly, while 1,992 cities, towns, and villages were consolidated into 587 municipalities by April 2006, there were as many as 1,260 municipalities whose borders remained intact. As a result of these mergers, the number of municipal politicians shrank in the first group of newly established municipalities but not in the latter. By focusing on this important intracountry variation, we can systematically examine how the reduction in the number of municipal politicians altered national election results.

We expect that the political party relying most extensively on local politicians' efforts for electoral mobilization and monitoring will suffer an electoral slump as the number of municipal politicians is swiftly reduced. By examining the change in electoral returns between the 2001 and 2007 upper house (Sangiin) elections, ${ }^{1}$ we will 
show that turnout is lower and the vote share of the ruling Liberal Democratic Party (LDP) is smaller in municipalities with mergers than in those without. This indicates that mergers of municipalities and the resultant decline in the number of municipal politicians did indeed undermine the LDP's ability to mobilize and monitor voters.

There remains, however, a puzzle: Why then did the ruling party promote municipal mergers that would, at a glance, impair their longtime strongholds? Although examining this question is beyond the scope of this article, our provisional argument is that the ruling party promoted municipal mergers to reallocate resources from rural areas to urban areas, so that the party could improve its electoral prospects in urban, marginal districts under the new electoral rule. The observed effects of mergers were perhaps more dramatic and devastating than the LDP initially expected. In a later section of this article, we will elaborate on our argument. ${ }^{2}$

The most relevant to our study is Shimizu's (2012) recent study published in this journal. By comparing actual election results of postmerger prefectural assembly elections with simulated results under a counterfactual scenario of no municipal merger, Shimizu reached essentially the same conclusion as ours: "municipal mergers have drastically weakened the LDP's support base" (381). Her article, however, focuses on prefectural elections and has little discussion or analysis on how municipal mergers affected the LDP's electoral machines in national elections. Although her article opened up an interesting avenue for discussion, we think that no research is complete without examining the mergers' impacts on national elections, in which LDP experienced historic defeats. ${ }^{3}$

Our article is expected to make contributions not only to the literature of Japanese politics but also to the comparative literature of electoral politics and behavior. There are important existing studies that also shed light on the role of local politicians in affecting national election outcomes. For example, Gaines (1999), Jones (1997), and Samuels (2000) study the impacts of subnational elections (e.g., timing of gubernatorial elections) on national election outcomes, particularly on the effective number of parties in Canada, Argentina, and Brazil, respectively. In the literature of Japanese politics, Ishikawa (1995) and Asano (1998) discuss the "boar's year effect"-a turnout decline in upper house elections in years when they are preceded by nationwide subnational elections by only a few months. ${ }^{4}$ These studies, however, do not necessarily provide a behavioral foundation to understand subnational politicians' incentives and 
their impacts on electoral mobilization and monitoring. By combining in-depth qualitative and institutional analysis of mobilization and monitoring activities by municipal politicians in Japan with rigorous statistical analysis, we intend to improve our theoretical understanding of the roles of local politicians in national election outcomes.

The rest of this article is organized in the following manner. In the next section, we will discuss the role of municipal politicians in mobilizing citizens to vote for the LDP and how they monitor voters' behavior. Then we will analyze upper house election data aggregated at the municipal level, followed by our conclusion. In the Appendix, we discuss postmerger political changes in recent years.

\section{Municipal Politicians and Municipal Mergers in Japan}

The way local politicians monitor and mobilize voters at large is defined by institutionalized incentives. Therefore, in this section, we first describe the institutional contexts in which Japanese local governments are embedded. We then derive hypotheses regarding how consolidation of municipal governments will affect the electoral fortunes of the governing party.

Institutional Origins of Clientelism in Japan

Unlike the US federal system in which the institutional features of local governments differ dramatically from state to state, the basic political structure of local governments in Japan is homogeneous throughout the nation. Specifically, it is characterized as a three-tier system, where the national territory is partitioned into forty-seven prefectures with a mean population size of 2.7 million. These prefectures are further divided into 1,718 municipalities (as of April 1, 2014). The central government is a parliamentary system with a bicameral legislature, but both the prefectural and municipal governments operate as presidential systems (Soga and Machidori 2007), where prefectural governors and municipal mayors, respectively, serve as elected "presidents" in their geographic jurisdictions. All prefectural and municipal assemblies are unicameral, for they were originally designed to be an institutional check against the governors and mayors.

While the organizational structure of intergovernmental relations is similar across municipalities, their demography is not. Population sizes of Japanese municipalities range from the Village of Aogashima, with about 200 residents, to the City of Yokohama, with 3.6 
million residents. The features of government finance, in particular the municipalities' ability to collect tax revenues, are also heterogeneous. Given this size disparity both in terms of population and finance, an elaborate system of intergovernmental fiscal transfers was developed to ensure the same minimum national standard of public service..$^{5}$ It is quite natural that within this revenue-spending structure, the "common-pool problem" becomes a salient feature of distributive politics (Persson and Tabellini 2002). Members of the Diet, especially those affiliated with the LDP, are often compared to the "pipeline of pork" that delivers the stream of policy benefits from the national government to the neighborhoods (Fukui and Fukai 1996; Horiuchi and Saito 2003; Scheiner 2005). Municipal politicians are, then, the faucets at the end of each pipeline.

Additionally, municipal politicians are strongly motivated to pursue policy benefits targeted at their core supporters by the municipalitywide single nontransferable vote (SNTV) districts used in municipal assembly elections (Horiuchi 2005). This rule leads incumbent municipal legislators to seek thinly sliced benefits, instead of large externality programs, as Myerson's (1993) vote-buying model predicts. Let us demonstrate this point with an example. Suppose that there is a town with a population size slightly below 10,000 . In a typical town assembly election, there are about nineteen or twenty candidates contesting the seats in this eighteen-member district. If turnout is not very different from normal elections, the number of votes required to win a seat would be about 300 , depending upon how votes are divided among candidates. ${ }^{6}$ In this institutional environment, most candidates attempt to divide their support bases by means of geography. ${ }^{7}$ Since this geographic method of vote division is only informal, however, new entrants can easily perturb the existing distributions of votes. Thus, to secure their reelection, incumbents strive to cater to their constituents by expending efforts to deliver intensive benefits to their core supporters and their families, like the recruitment and promotion of public servants and teachers, the provision of patronage jobs (e.g., snow removal), and the purchase of assets above market rate (e.g., land sites for road projects) ${ }^{8}$

Given these two institutional features of intergovernmental fiscal transfers and municipal assembly electoral systems, most municipal politicians strive to develop dense social networks to reap resources that are essential to their own reelection. Furthermore, they cultivate connections to national-level politicians in power-particularly Diet members affiliated with the LDP. In turn, LDP candidates running for 
the Diet are dependent on these municipal politicians to build up the support base for their own national elections.

\section{Electoral Implications of Municipal Mergers}

The good old days for municipal politicians, however, are passing since the Japanese government started a process of consolidating municipalities in 1999. ${ }^{9}$ The government introduced financial incentives to reward municipalities that would sign merger contracts by March 31, 2006, which was the end of fiscal year 2005. As a result, after the number of municipalities stayed at about 3,300 for nearly four decades, the total number of municipalities decreased to 1,847 by April 1, 2006. As many as 1,106 municipalities were merged between January 2005 and March 2006 alone.

Since the central government promoted consolidation of municipal government by fiscal incentives rather than by binding legal stipulations, there was a wide variation in each municipality's willingness to merge with other neighboring municipalities. Accordingly, this local government reform had a geographically mottled pattern. Among the 3,252 municipalities that existed on January 1, 2000, 1,992 (61 percent) of them underwent mergers, while the borders for the remaining 1,260 municipalities remained unchanged. This intracountry variation is helpful in estimating the impact of municipal mergers on electoral results because we can retain the status quo municipalities as a control group for comparison.

By way of this wave of municipal mergers in Japan, the central government intended to reduce the number of municipal government officials, particularly mayors and municipal assembly members. The reduction in the number of municipal politicians was implemented through an existing institutional arrangement. As is shown in Figure 1, Article 91 of the Chihō Jichi Hō (Local Autonomy Law) stipulates the maximum municipal assembly size as a step function of municipal population sizes, which can be approximated by a logarithmic curve (i.e., the straight predicted line in this figure).

One natural consequence of this law is that the number of municipal legislators per capita is smaller when the municipal population is larger. Therefore, municipal mergers inevitably reduce not only the number of municipal mayors but also municipal assembly members. Note that each municipality can decide the actual assembly size as long as it is under this maximum. Nationally aggregated statistics suggest that, on average, the actual assembly sizes are about 80 percent of the legally stipulated maximum, which remains almost con- 
Figure 1 Municipal Assembly Size and Municipal Population

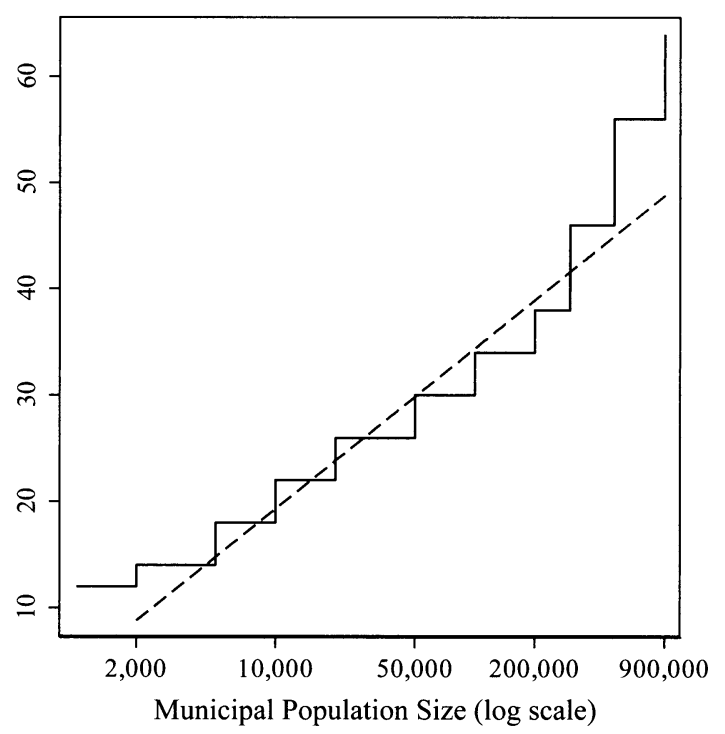

Note: The solid line indicates the legally stipulated maximum assembly size, whereas the dashed line indicates the OLS regression line; maximum assembly size $=-41.0+6.549 \ln (\mathrm{mu}-$ nicipal population).

stant before and after municipal mergers (Sōmushō Jichi Gyōseikyoku Senkyobu 2007). ${ }^{10}$ Because these two groups of politicians-mayors and municipal legislators-play an important role both during electoral campaigns and in community-based political activities for national-level LDP politicians, the restructuring of municipal governments is expected to affect voter turnout and the LDP's vote-procuring capability. More specifically, we present the following two hypotheses:

1. The LDP's vote share in national elections is lower in those municipalities that experienced mergers in the recent past; and

2. Turnout is also lower in those municipalities.

There are three channels through which the consolidation of municipalities suppresses the turnout and the vote share. First, municipal mergers directly translated into a reduction of the number of mayors, most of whom were informally affiliated with the LDP's 
party organization and/or its Diet members' personal support organizations known as köenkai. Since these mayors are individually strong "presidents" in their jurisdictions, firing them led to the loss of their capability to mobilize municipal assembly members and voters. It is important to note that as of late 2006, there were only two municipal mayors who officially labeled themselves as LDP partisans among 1,844 municipal mayors throughout Japan (Sōmushō Jichi Gyōseikyoku Senkyobu 2007). It is widely known, however, that their nonpartisan status was a disguise. They labeled themselves as nonpartisans in order to avoid competition from the opposition parties' candidates. This nonpartisan-in-disguise strategy also allowed them to penetrate into local communities more easily and deeply than would be possible under an official LDP label. Local organizations of the opposition parties were effectively neutralized by this tactic (Scheiner 2005).

Second, disbanding municipal assemblies weakened the LDP's vote-getting capability through a reduction of the total number of municipal assembly members per voter, as we already discussed. As of December 1, 2002, there were as many as 58,254 incumbents serving in office, ${ }^{11}$ but the total number of municipal assembly members decreased to 40,350 by the end of calendar year 2006 (Somushō Jichi Gyōseikyoku Senkyobu 2007). For example, the City of Seiyo was established in April 2004 by merging five nearby towns in Ehime, a rural prefecture on the southern island of Shikoku. There used to be a total of seventy-eight local assembly members in these towns, but after the establishment of this new city, the number of assembly members was cut to thirty-one. ${ }^{12}$ This reduction in the number of seats led directly to a reduction in the number of LDP affiliates. As in the case of "nonpartisan" mayors, roughly 75 to 80 percent of the assembly members officially labeled themselves as nonpartisans when running for reelection (Somushō Jichi Gyōseikyoku Senkyobu 2007), but most of these independents were affiliated with the local branch organizations of the LDP and/or the koenkai of LDP Diet members.

The former mayors and municipal assembly members who had to retire due to municipal mergers were reported to be almost dormant during the 2007 campaign period, despite being asked by the LDP to stay in the party and to participate in the campaign for the national elections. ${ }^{13}$ Previously, these former incumbents mobilized voters in national elections to canvass their supporters and contribute to their own reelection campaign efforts. After the mergers, they had no more 
concerns for their own reelection bids, so they became passive participants in the electoral process rather than active mobilizers. A survey conducted in 2012 by one of the authors of this article supports this point. Yamada (2013) finds that voters in merged municipalities were more likely than voters in municipalities that remained intact to report that their ties with municipal assembly members weakened after mergers. ${ }^{14}$

We should note that these retired politicians lost monetary incentives for mobilization. Previously, active participation in all levels of the electoral process directly increased the chances of being elected as a mayor or municipal assembly member, which entailed monthly stipends and other substantial fringe benefits, ranging from lucrative pension plans to fully paid study tours. ${ }^{15}$ Since electoral campaign activities cost them both time and money, it is no wonder that the amount of effort they were willing to invest ended up being commensurate with the size of payment. After restructuring these municipal political elites, the LDP needed to persuade them to mobilize voters on a purely voluntary basis.

The above two channels relate to local politicians' electoral mobilization efforts, but the remaining channel concerns their roles in monitoring and possibly punishing voters in the event of defection (Nichter 2008; Stokes 2005). In Japan, there is an abundance of anecdotal evidence suggesting that local political elites could monitor the voting behavior of their neighbors with surprising accuracy (Horiuchi 2005; Ishikawa 1999). For example, senior members of local communal organizations often monitor the polling stations for the sake of fairness in voting. In polling stations in Japan, voters are required to write out the candidate's full name in a ballot, instead of punching a hole or pushing a button. Although thin steel fences partition voting booths, the voting booths are half open without anything hiding voters' backs. Since the number of strokes in the Japanese characters serves as an easy clue revealing whom the person voted for, proper conduct in voting takes place under substantial public pressure. Delivery of benefits can be revoked in the event of a voter's defection. When the number of municipal legislators shrinks due to a merger, however, both monitoring and sanction become increasingly costly and imperfect. As a result, voters feel less pressure to turn out and vote for the LDP.

While consolidation of municipal governments reduced the LDP's capability to deliver benefits and to monitor voting behavior in the neighborhoods, the other parties' support base remained rela- 
tively intact, at least during the period of our investigation (20012007). For instance, labor unions of municipal public servants comprised one important support base for the Democratic Party of Japan (DPJ), but even after municipalities were merged, these municipal officials could not be easily fired due to the legal clauses that protected their employment.

\section{Data Analysis}

To test the two hypotheses presented in the previous section, we focus on the results of Japan's upper house elections in 2007specifically, changes in the election results from 2001 to 2007. Unlike most existing empirical studies on Japanese elections and politics, we examine the upper house-rather than lower house-electoral data, and we focus on this specific period, for two reasons. First, to estimate the direct and immediate political consequences of municipal mergers, it is necessary to focus on the first national-level election after the recent wave of municipal mergers, which is the 2007 upper house election. ${ }^{16}$ Second, since electoral districts correspond to forty-seven prefectures, we can examine the determinants of election results across municipalities within each prefecture. This within-prefecture analysis takes advantage of prefecture-specific fixed effects, which effectively hold constant a wide range of observable and unobservable electoral district-level attributes.

With a focus on these elections, we examine how municipal mergers affected changes in the distribution of votes in the 2007 upper house election vis-à-vis those in the 2001 upper house election. Specifically, the dependent variables for our analysis are the change in the vote share of governing parties (i.e., the total number of votes for governing parties divided by the total number of valid votes) and voter turnout. ${ }^{17}$ We compare whether the changes in these dependent variables are significantly and substantively different between municipalities that experienced a merger vis-à-vis municipalities that did not.

This estimation is based on a difference-in-differences (DD) research design, which is widely used in observational studies aimed to make causal inference. By taking the first-order difference on both sides of our regression equation, all observable and unobservable, municipality-specific characteristics that did not change within the period of investigation (from 2001 to 2007) are controlled. They include premerger historical and cultural attributes and economic conditions of municipalities, which are likely to be important deter- 
minants of municipal mergers. In addition, by adding prefecture fixed effects in our DD model, all prefecture-specific, firstdifferenced changes are controlled. They include the changing nature of electoral competition in each prefecture. Furthermore, we add a range of observable municipality-specific and time-variant variables in our model. Since these variables changed concurrently with municipal mergers and the degrees of these changes vary across municipalities, to isolate the effect of mergers that happened during the same period of investigation, these covariates must be controlled. Given this design with a range of controls, we make a "parallel trend" assumption according to the methodological literature of causal inference. Specifically, we assume that a change in the dependent variable for a "treated" case (i.e., a municipality that merged), if it had not been treated, would have been the same as the change in the dependent variable for an untreated case (i.e., a municipality that did not merge).

The unit of analysis is 1,826 municipalities (cities, towns, and villages), as they were composed for the upper house election held on July $29,2007 .{ }^{18}$ Among them, 557 municipalities were established as a result of municipal mergers during the period between the two elections (hereinafter "new" municipalities), while the rest of the municipalities existed as of the 2001 and 2007 elections (hereinafter "old" municipalities). ${ }^{19}$ For the merged municipalities, the premerger data were aggregated at the level of new municipalities.

There was another upper house election in 2004, but we compare the results of 2001 and 2007 in order to cover the entire period of recent municipal mergers, during which most municipal mergers took place (i.e., between April 2003 and March 2006). We also note that the members of Japan's upper house serve for six years, and half of them are up for election every three years. Therefore, electoral contests in 2007 in each district are more readily comparable to those in $2001 .{ }^{20}$

The electoral system used in the 2001 and 2007 upper house elections is the combination of the open-list proportional representation (PR) system with a nationwide at-large district, and the SNTV system with prefecture-wide districts with the district magnitude ranging from 1 to 5 . In our analysis, we use municipality-level results of prefecture-wide SNTV elections. ${ }^{21}$ As we noted above, by running fixed-effect regressions, we are able to examine the determinants of variations in election results within each prefecture after holding variables specific to each electoral district (i.e., prefecture) constant. 
The descriptive statistics in Table 1 suggest that on (weighted) average, voter turnout increased by 2.28 points and the governing parties' vote share dropped by 12.82 points between the 2001 and 2007 upper house elections. More importantly, new municipalities, as compared to old municipalities, had the smaller magnitude of increase in voter turnout (1.69 points, as compared to 2.64 points) and the larger magnitude of decrease in the vote share of governing parties ( -14.39 points, as compared to -11.87 points). These results are consistent with our expectations.

To cope with other potentially confounding factors and to satisfy the parallel trend assumption in our difference-in-differences design, which we explained earlier, we also run regression analyses with the following model:

$$
\Delta Y_{i j}=\beta_{0}+\beta_{1} X_{i j}+\beta_{2} Z_{i j}+\delta_{j}+\varepsilon_{i j}
$$

where $\Delta Y_{i j}$ is the change in an outcome variable in Municipality $i=$ $\{1, \ldots, 1,826\}$ in Prefecture $j=\{1, \ldots, 47\} ; X_{i j}$ is a dummy variable coded 1 if Municipality $i$ in Prefecture $j$ is a new municipality established as a result of municipal merger during the period between the two elections $(N=557)$, and 0 otherwise $(N=1,269) ; Z_{i j}$ is a set of control variables, which vary across municipalities and across years; $\delta_{j}$ is a prefecture-specific fixed effect; and $\varepsilon_{i j}$ is an error term.

In addition to the dichotomous independent variable, which is most readily interpretable, we also analyze two different measures of mergers. ${ }^{22}$ We use them to examine whether the estimated effects of the dichotomous merger dummy do, indeed, reflect the effects of reduction in the number of local political elites. First, we use the number of municipalities as of the 2001 upper house elections. It is 1 for old municipalities that did not experience municipal mergers, whereas it is more than 1 (maximum 14) for new municipalities. This variable directly measures the reduction in the number of mayors. The second variable is the decrease in the number of the maximum number of legislative seats stipulated by the Local Autonomy Law, which we explained earlier. Specifically, we use the following formula to calculate this variable:

$$
-\left(\operatorname{Max}_{i j, 2007}-\operatorname{Max}_{i j, 2001}\right) / \operatorname{Max}_{i j, 2001}
$$

where $\operatorname{Max}_{i, 2007}$ is the maximum assembly size of Municipality $i=$ $\{1, \ldots, 1,826\}$ in Prefecture $j$ based on the population as of the end of 
Table 1 Descriptive Statistics

\begin{tabular}{lrrrc}
\hline Variable & Mean & S.D. & Min. & Max. \\
\hline$\Delta$ Governing parties' vote share & -12.82 & 7.49 & -54.14 & 50.81 \\
$\quad X_{i j}=0$ & -11.87 & 6.42 & -50.14 & 50.81 \\
$\quad X_{i j}=1$ & -14.39 & 8.77 & -54.14 & 21.62 \\
$\Delta$ Voter turnout & 2.28 & 3.14 & -24.01 & 30.04 \\
$\quad X_{i j}=0$ & 2.64 & 2.78 & -24.01 & 30.04 \\
$\quad X_{i j}=1$ & 1.69 & 3.58 & -14.06 & 16.57 \\
Municipal merger $\{0,1\}$ & 0.38 & 0.48 & 0 & 1 \\
Number of municipalities, 2001 & 2.26 & 2.31 & 1 & 14 \\
Decrease in max. number of seats & 0.29 & 0.28 & -0.17 & 0.87 \\
Electoral margin, 2000 lower house & 10.88 & 18.97 & -45.20 & 68.02 \\
New, ordinance-designated city $\{0,1\}$ & 0.03 & 0.18 & 0 & 1 \\
$\Delta$ Population, total & 0.01 & 0.04 & -0.40 & 0.68 \\
$\Delta$ Population ratio, age 65+ & 0.16 & 0.06 & -0.17 & 0.44 \\
$\Delta$ Working pop. ratio, agriculture & -0.04 & 0.11 & -1.91 & 1.00 \\
$\Delta$ Working pop. ratio, construction & -0.13 & 0.05 & -1.29 & 1.28 \\
$\Delta$ Total transfers per capita & -0.17 & 0.25 & -2.56 & 0.90 \\
\hline
\end{tabular}

Notes: The total number of observations (municipalities) is 1,826: 557 new municipalities established by municipal merger $\left(X_{i j}=1\right)$ and 1,269 remaining municipalities $\left(X_{i j}=0\right)$. All observations are weighted by the total number of eligible voters in each municipality.

March 2007, and $\operatorname{Max}_{i j, 2001}$ is that as of the end of March 2001. For each of the new municipalities, $\operatorname{Max}_{i, 2001}$ is the total number of seats in premerger municipalities. This variable roughly measures the reduction in the number of municipal legislators. We expect that these two alternative main independent variables will have negative effects on the outcome variables. The coefficients of the latter variable, however, are expected to exhibit attenuation bias due to measurement errors.

We also include the following control variables, and their descriptive statistics are reported in Table 1. First, we include the level of the governing party candidates' winning margin in the 2000 lower house election. Specifically, we use the difference in votes between the candidate from the governing coalition and the largestvote-getting candidate from the opposition camp divided by the sum of valid votes. While there is a substantial literature treating municipal mergers as a means of reducing transfers to local governments and dealing with demographic challenges in rural areas (e.g., Sasaki 2004; Weese 2012; Yokomichi 2007), there is also evidence that municipal mergers were caused by political considerations (Horiuchi, 
Saito, and Yamada 2009; Rosenbluth, Saito, and Yamada 2011; Yamada 2013). In particular, it appears that municipal mergers were more prevalent in districts where the LDP incumbent enjoyed a more comfortable victory (Horiuchi, Saito, and Yamada 2009). Thus, it is appropriate to include a control variable for the margin of victory.

Second, populous cities designated by ordinance (seirei shitei toshi) need special attention. As of the 2007 upper house election, there were seventeen such cities. As a set of policymaking authorities, which are normally invested to prefectural governments, is delegated to these cities, the national government's involvement is strengthened while the prefectural government's is undermined. Citylevel politicians may face mixed incentives that are distinct from politicians in other municipalities. By taking the first-order difference, the time-invariant, city-specific effects can be controlled for all ordinance-designated cities except five new ones (Saitama, Niigata, Shizuoka, Hamamatsu, and Sakai), which were established between the 2001 and 2007 upper house elections. These five cities take a value of 1 for the "New, Ordinance-Designated City" variable, while other municipalities are set to 0 .

We also include four variables that measure the changes in demographic structure from the 2000 census to the 2005 census (Somushō Tōkeikyoku 2002, 2007). ${ }^{23}$ Since these changes are concurrent with municipal mergers and changes in electoral behavior, they must be controlled to meet the parallel trend assumption in the difference-in-differences design. The first one is the change in the total municipal population (in $\log$ ). In the 2007 upper house election, voter turnout increased most distinctively in urban areas, and such urban voters were said to have cast protest votes against the governing parties, particularly the LDP. The variable measuring an increase (decrease) in the total municipal population, at least in part due to population inflows (outflows), is a proxy for the presence (nonpresence) of such nonorganized voters whose voting decisions are susceptible to "air battles" of election campaigns (e.g., TV debates and ads). ${ }^{24}$

Second, we include the change in the percentage of the elderly population aged sixty-five and over (in $\log$ ), because this specific portion of the population is expected to be sensitive to the most important issue in the 2007 elections - the government's mishandling of pension payment records. The other two demographic variables are the change in the percentage of the working population in the agricultural sector (in log), and the change in the percentage of the 
working population in the construction sector (in log). We add them because postelection media reports and academic studies suggest that the LDP lost votes most significantly among agricultural and construction workers, who had been loyal supporters of the party since its establishment in 1955 (e.g., Imai and Kabashima 2007).

Another first-differenced control variable is the change in total transfers per capita (in log) between fiscal year 2000 and 2006. ${ }^{25}$ The total transfers include the following three components: the formulaically allocated portion of grant-in-aid (chihō kōfuzei futsū $k \bar{o} f u k i n)$, the grant-in-aid that is allocated discretionarily (chihō kofuzei tokubestu kōfukin), and the national treasury disbursement (kokko shishutsukin), which is project-based subsidies. One of the officially stated objectives of drastic municipal mergers in the early 2000s was to cut back the overall size of intergovernmental fiscal transfers, on which small municipalities had been heavily dependent, and to promote local economic growth by bringing about the advantage of scale (Jiyū Minshutō Gyōsei Kaikaku Suishin Honbu 1998). ${ }^{26}$

We also add prefecture-specific fixed effects on the right-hand side of our regression model. As we emphasized earlier, these fixed effects are effective in controlling a range of observable and unobservable characteristics specific to each electoral district-each prefecture-in upper house elections. As we already control municipalityspecific and time-invariant characteristics by taking the first difference, the fixed effects effectively control prefecture-specific changes between the 2001 and the 2007 upper house elections. They include changes in district-level competitiveness, candidate quality, the number of candidates, and the apportionment of seats (i.e., the total population per seat). They also control prefecture-specific changes in other political/electoral variables, including changes in prefectural governors' partisanship, as well as changes in relations between the prefecture government and the governing parties in the national Diet.

Tables 2 and 3 report the results of regression analysis for the governing parties' vote share and the turnout rate, respectively. For each of the two outcome variables, we estimated six models. Three of them are the simple regression models without any covariates, and the other three incorporate control variables and prefecture-specific fixed effects.

The simple regression models suggest the validity of our hypotheses (columns 1-3). On average, when compared to old municipalities, the new municipalities tend to have the larger magni- 
Table 2 Regression Results, Change in Governing Parties' Vote Share

\begin{tabular}{|c|c|c|c|c|c|c|}
\hline & 1 & 2 & 3 & 4 & 5 & 6 \\
\hline Municipal merger $\{0,1\}$ & $\begin{array}{l}-2.52 * * \\
(0.36)\end{array}$ & & & $\begin{array}{c}-0.98 * * \\
(0.25)\end{array}$ & & \\
\hline $\begin{array}{l}\text { Number of municipalities } \\
2001\end{array}$ & & $\begin{array}{l}-0.64^{* *} \\
(0.07)\end{array}$ & & & $\begin{array}{l}-0.23 * * \\
(0.05)\end{array}$ & \\
\hline $\begin{array}{l}\text { Decrease in max. num. of } \\
\text { seats }\end{array}$ & & & $\begin{array}{l}-5.38^{* *} \\
(0.61)\end{array}$ & & & $\begin{array}{l}-2.29 * * \\
(0.45)\end{array}$ \\
\hline $\begin{array}{l}\text { Electoral margin, 2000, in } \\
\text { lower house }\end{array}$ & & & & $\begin{array}{l}-0.05 * * \\
(0.01)\end{array}$ & $\begin{array}{l}-0.05^{* *} \\
(0.01)\end{array}$ & $\begin{array}{l}-0.05^{* *} \\
(0.01)\end{array}$ \\
\hline $\begin{array}{l}\text { New, ordinance-designate } \\
\quad \text { city }\{0,1\}\end{array}$ & & & & $\begin{array}{r}1.34^{*} \\
(0.59)\end{array}$ & $\begin{array}{r}1.52^{*} \\
(0.59)\end{array}$ & $\begin{array}{l}1.51^{*} \\
(0.59)\end{array}$ \\
\hline$\Delta$ Population, total & & & & $\begin{array}{l}-8.19^{* *} \\
(2.94)\end{array}$ & $\begin{array}{l}-7.93 * * \\
(2.93)\end{array}$ & $\begin{array}{l}{ }^{*}-9.37^{* *} \\
(2.96)\end{array}$ \\
\hline$\Delta$ Population ratio, age 6 & & & & $\begin{array}{l}5.20^{*} \\
(2.23)\end{array}$ & $\begin{array}{c}5.23^{*} \\
(2.23)\end{array}$ & $\begin{array}{c}4.28 \\
(2.25)\end{array}$ \\
\hline$\Delta$ Working pop. ratio, agr & iculture & & & $\begin{array}{c}-1.92^{*} \\
(0.94)\end{array}$ & $\begin{array}{c}-1.98^{*} \\
(0.94)\end{array}$ & $\begin{array}{l}-1.84^{*} \\
(0.93)\end{array}$ \\
\hline$\Delta$ Working pop. ratio, cor & istruction & & & $\begin{array}{c}-4.70^{*} \\
(1.99)\end{array}$ & $\begin{array}{l}-4.71^{*} \\
(1.99)\end{array}$ & $\begin{array}{c}-4.28^{*} \\
(1.99)\end{array}$ \\
\hline$\Delta$ Total transfers per capi & & & & $\begin{array}{c}0.65 \\
(0.45)\end{array}$ & $\begin{array}{c}0.47 \\
(0.44)\end{array}$ & $\begin{array}{c}0.70 \\
(0.45)\end{array}$ \\
\hline Constant & $\begin{array}{l}-11.87^{* *} \\
(0.22)\end{array}$ & $\begin{array}{l}-11.38^{* *} \\
\quad(0.24)\end{array}$ & $\begin{array}{l}-11.26 * * \\
(0.25)\end{array}$ & $\begin{array}{l}-8.24 * * \\
(1.07)\end{array}$ & $\begin{array}{l}-8.11^{* *} \\
(1.07)\end{array}$ & $\begin{array}{l}-7.70^{* *} \\
(1.08)\end{array}$ \\
\hline Prefecture fixed effects & No & No & No & Yes & Yes & Yes \\
\hline R-square & 0.03 & 0.04 & 0.04 & 0.75 & 0.76 & 0.76 \\
\hline Adjusted R-squared & 0.03 & 0.04 & 0.04 & 0.75 & 0.75 & 0.75 \\
\hline F statistic & 49.93 & 72.84 & $77.75 \quad 1$ & 100.73 & $101.08 \quad 1$ & 101.48 \\
\hline Root MSE & 7.39 & 7.34 & 7.33 & 3.77 & 3.76 & 3.76 \\
\hline
\end{tabular}

Notes: The number of observations (municipalities) is 1,826. All observations are weighted by the total number of eligible voters in each municipality. Standard errors are in parentheses. All firstdifferenced right-hand-side variables are differences in log values. ${ }^{*} p<.05 ; * * p<.01$.

tude of decrease in governing parties' vote share and the smaller magnitude of increase in voter turnout. Even after adding other covariates and the prefecture fixed effects, these estimated effects have the same sign and are statistically significant (columns 4-6).

The substantial effects are large, even in conservative estimates based on specifications with prefecture fixed effects. In new municipalities, the decrease in the governing party vote share is 0.98 percentage points larger, and the increase in voter turnout is 0.54 percentage points smaller than in old municipalities (column 4). As we noted, the governing parties' vote share declined sharply nationwide between the 2001 and the 2007 elections-by 12.82 percentage 
Table 3 Regression Results, Change in Voter Turnout

\begin{tabular}{|c|c|c|c|c|c|c|}
\hline & 1 & 2 & 3 & 4 & 5 & 6 \\
\hline Municipal merger $\{0,1\}$ & $\begin{array}{l}-0.96^{* *} \\
(0.15)\end{array}$ & & & $\begin{array}{l}-0.54^{* *} \\
(0.14)\end{array}$ & & \\
\hline $\begin{array}{l}\text { Number of municipalities, } \\
2001\end{array}$ & & $\begin{array}{l}-0.20 * * \\
(0.03)\end{array}$ & & & $\begin{array}{l}-0.13 * * \\
(0.03)\end{array}$ & \\
\hline $\begin{array}{l}\text { Decrease in max. num. of } \\
\text { seats }\end{array}$ & & & $\begin{array}{l}-2.05^{* *} \\
(0.26)\end{array}$ & & & $\begin{array}{l}-1.25^{* *} \\
(0.25)\end{array}$ \\
\hline $\begin{array}{l}\text { Electoral margin, } 2000 \text { in } \\
\text { lower house }\end{array}$ & & & & $\begin{array}{c}0.00 \\
(0.00)\end{array}$ & $\begin{array}{c}0.00 \\
(0.00)\end{array}$ & $\begin{array}{c}0.00 \\
(0.00)\end{array}$ \\
\hline $\begin{array}{l}\text { New, ordinance-designated } \\
\quad \text { city }\{0,1\}\end{array}$ & & & & $\begin{array}{l}2.24^{* *} \\
(0.33)\end{array}$ & $\begin{array}{l}2.35^{* *} \\
(0.33)\end{array}$ & $\begin{array}{l}2.33 * * \\
(0.33)\end{array}$ \\
\hline$\Delta$ Population, total & & & & $\begin{array}{l}7.93 * * \\
(1.63)\end{array}$ & $\begin{array}{l}8.05^{* *} \\
(1.62)\end{array}$ & $\begin{array}{l}7.29 * * \\
(1.64)\end{array}$ \\
\hline$\Delta$ Population ratio, age 65 & & & & $\begin{array}{l}8.11^{* *} \\
(1.24)\end{array}$ & $\begin{array}{l}8.12^{* *} \\
(1.23)\end{array}$ & $\begin{array}{l}7.62^{* *} \\
(1.24)\end{array}$ \\
\hline$\Delta$ Working pop. ratio, agri & ulture & & & $\begin{array}{l}-0.40 \\
(0.52)\end{array}$ & $\begin{array}{l}-0.43 \\
(0.52)\end{array}$ & $\begin{array}{l}-0.36 \\
(0.52)\end{array}$ \\
\hline$\Delta$ Working pop. ratio, cons & truction & & & $\begin{array}{l}1.40 \\
(1.10)\end{array}$ & $\begin{array}{c}1.40 \\
(1.10)\end{array}$ & $\begin{array}{l}1.63 \\
(1.10)\end{array}$ \\
\hline$\Delta$ Total transfers per capita & & & & $\begin{array}{c}-0.05 \\
(0.25)\end{array}$ & $\begin{array}{c}-0.15 \\
(0.24)\end{array}$ & $\begin{array}{l}-0.02 \\
(0.25)\end{array}$ \\
\hline Constant & $\begin{array}{l}2.64^{* *} \\
(0.09)\end{array}$ & $\begin{array}{l}2.73^{* *} \\
(0.10)\end{array}$ & $\begin{array}{l}2.88^{* *} \\
(0.10)\end{array}$ & $\begin{array}{c}0.73 \\
(0.59)\end{array}$ & $\begin{array}{c}0.81 \\
(0.59)\end{array}$ & $\begin{array}{c}1.02 \\
(0.60)\end{array}$ \\
\hline Prefecture fixed effects & No & No & No & Yes & Yes & Yes \\
\hline R-square & 0.02 & 0.02 & 0.03 & 0.57 & 0.57 & 0.58 \\
\hline Adjusted R-squared & 0.02 & 0.02 & 0.03 & 0.56 & 0.56 & 0.56 \\
\hline F statistic & 40.63 & 40.21 & 63.57 & 44.06 & 44.3 & 44.47 \\
\hline Root MSE & 3.11 & 3.11 & 3.09 & 2.08 & 2.08 & 2.08 \\
\hline
\end{tabular}

Notes: The number of observations (municipalities) is 1,826 . All observations are weighted by the total number of eligible voters in each municipality. Standard errors are in parentheses. All firstdifferenced right-hand-side variables are differences in log values. ${ }^{*} p<.05 ;{ }^{* *} p<.01$.

points, on average. The municipal mergers' marginal effect is equivalent to 7.6 percent of the national swing $(0.98 \div 12.82)$. Between the two elections, voter turnout increased by 2.28 percentage points, on average, but the magnitude of this increase is considerably lower in the new municipalities.

The two other main independent variables measuring municipal mergers unsurprisingly show similar substantial effects. As one municipality is merged into a new municipality (equivalently, as one municipal mayor loses his/her job), the change in the government coalitions' vote share and the turnout rate drop by 0.23 and 0.13 percentage points, respectively (column 5). Since the mean reduction 
among new municipalities is 4.34 , on average, the decrease in the government coalitions' vote share is larger by 1.0 percentage points, while the increase in turnout rate is lower by 0.56 percentage points in new municipalities than in old municipalities. The effects of the reduction in the number of municipal assembly members are also similar. When the maximum assembly sizes are reduced by half (i.e., when "Decrease in Max. Num. of Seats" changes from 0 to 0.5), which is roughly equivalent to a change from -1 standard deviation ( 0.28$)$ from the mean $(0.29)$ to +1 standard deviation from the mean, the change in the government coalition's vote share and the turnout rate drop 1.1 and 0.6 percentage points, respectively (column 6 ). The similarity in substantial effects of our three main independent variables suggests that the effects of municipal mergers, as suggested by models using the simple dichotomous variable, are indeed measuring the effects of reduction in the number of mayors and municipal legislators.

\section{Conclusion}

Local politicians in Japan have long played important roles in mobilizing voters for national parties. The occurrence of mergers and the reliance on local politicians, however, were not uniformly distributed across space and political parties; mergers were concentrated in rural areas, and the LDP was more dependent than other parties on local politicians. Thus, municipal mergers resulted in the swift removal of the LDP's campaign activists in its stronghold, and the party had to compete in national elections under the new strategic environment. As we demonstrated in this article, voter turnout and the LDP's vote share are indeed lower in municipalities that experienced consolidations than in those that remained intact. The swift reduction in the number of municipal politicians allows us to shed light on the underinvestigated role of local politicians in national elections. Focusing on this unique situation in Japan, we showed that municipal politicians are indeed indispensable human resources for candidates running for the national parliament. The party that abruptly lost municipal politicians suffered electoral slumps shortly after these paid campaign activists had disappeared.

Having shown that municipal mergers impacted national-level election outcomes, our next research agenda includes the analysis of policy consequences at the national level. To the extent that political parties accommodate the demands of their core activists, municipal politicians in rural areas and the interests they represent are likely to 
have significant influences on the LDP's platform and policy outcomes. Given that the LDP (or other parties for that matter) could no longer rely on municipal politicians as they did in the past, the party's need to cater to their interests should have declined accordingly. In other words, municipal mergers led to a sudden and drastic change in the composition of core activists within the party. We expect that as a result of this change, the priority of the LDP and other parties has shifted away from organized rural interests. This argument is worth further empirical inquiry.

Looking beyond the Japanese context, in many of the established democracies in the world, local politicians play important roles in national elections. Despite the fact that there exist a large number of locally elected politicians in most democracies, the existing research on intergovernmental relations has placed its main focus on fiscal relationships without paying sufficient attention to their electoral roles. Our study demonstrates that fiscal transactions and other realms of public policy are deeply rooted in electoral incentives at both the national and the local levels, and it suggests the need for further comparative analyses of intergovernmental electoral relations and their policy consequences.

Yusaku Horiuchi is associate professor in the Department of Government at Dartmouth College and holds the Mitsui Chair in the Study of Japan. His research interests include comparative politics and political methodology. $\mathrm{He}$ is author of Institutions, Incentives and Electoral Participation in Japan: Cross-Level and CrossNational Perspectives (2005) and has published articles in American Journal of Political Science, American Political Science Review, Journal of Politics, Quarterly Journal of Political Science, and World Politics, among others.

Jun Saito is CEO and president of J Prep. He was formerly assistant professor of political science at Yale University and adjunct professor at Korea University. $\mathrm{He}$ is a winner of the 2011 Nikkei Prize for publications in economics. He was a member of the House of Representatives of the Japanese Diet from 2002 to 2003. His research expertise pertains to Japanese electoral and legislative politics.

Kyohei Yamada is assistant professor in the Graduate School of International Relations at International University of Japan. His research interests include comparative politics, intergovernmental relations, and Japanese politics.

\section{Appendix: Postmerger Political Changes}

After the 2007 upper house election, two lower house elections were held in 2009 and 2012, and two more upper house elections were held in 2010 and 2013. The LDP had a historic defeat in the 2009 
election and some splinters left the LDP before the 2010 election. The LDP experienced, however, a landslide victory in the 2012 lower house election, in which the party won a majority and returned to power. The LDP won another major victory in the 2013 upper house election and, together with the New Komeito, obtained a majority in the upper house as well. Then, how do our argument and findings square with the LDP's victories in the recent national elections?

First of all, we emphasize that this is a methodologically difficult question to answer. Although the dramatic "fall and rise" of the LDP in recent years is in and of itself intriguing, it is difficult to attribute whether and how municipal mergers per se affected these political changes. This is because political events after the completion of municipal mergers are, in methodological terminology, "post-treatment" (Rosenbaum 1984) events. Namely, a "treatment" (in our case, a municipal merger) affected the outcome of the first post-treatment event (the 2007 upper house election), which then affected subsequent events (the 2009-2013 elections). To be more concrete, after observing the devastating effects of municipal mergers in the first postmerger election in 2007, as well as in the 2009 election, it is likely that LDP leaders and backbenchers' incentives and behavior changed. A sequence of LDP defections before the 2010 election may be in part a consequence of municipal mergers and resultant dramatic defeats in 2007 and 2009. The LDP leaders' strategic efforts to attract floating voters in urban areas, as well the "nationalization" of elections (McElwain 2012; Reed, Scheiner, and Thies 2012), also may be resultant of the aftermath of municipal mergers.

Importantly, it is methodologically difficult to estimate the direct and indirect effects of municipal mergers in standard regression analysis. Let $X$ be our main independent variable - that is, whether a municipality merged or not - and $W$ be a variable measuring the outcome of the 2007 election. The dependent variable, $Y$, is a variable measuring the outcome of a more recent election, such as the 2013 election. As $W$ is a consequence of $X, W$ must change when $X$ changes. Therefore, it would not make sense to produce a coefficient estimate for the effect of $X$ on $Y$ when $W$ does not change. Given this problem of "post-treatment" (Rosenbaum 1984), one may alternatively suggest estimating the effect of $X$ on $Y$ without $W$. The interpretation of the coefficient estimate in this alternative specification would be difficult because the estimate effect of municipal mergers on the results of the 2013 elections would capture the effects of mergers, as well as a range of postmerger political changes that hap- 
pened for seven years and three months (i.e., from April 2006, the completion of municipal mergers, to July 2013, the 2013 upper house election). Decomposing what constitutes direct effects of municipal mergers and what constitutes other indirect mergers is a difficult task, methodologically. For this reason, instead of applying new and still controversial methods for "causal mediation analysis" (Imai et al. 2011), we estimate the immediate political consequences of municipal mergers by focusing on the first postmerger election.

Having acknowledged this methodological challenge, we argue that the recent landslide victories of the LDP are not necessarily inconsistent with our findings and arguments. Prior to the wave of municipal mergers, due to the intense mobilization efforts by local politicians, rural voters were highly organized, in the sense that they repeatedly and consistently turned out and voted for the LDP candidates in national elections. All else equal, if a voter is embedded in a dense network of mobilization, he or she would be less influenced by things like a change in his or her income and the prime minister's popularity. However, many of the rural municipalities went through mergers, and a large number of campaign activists in the countryside were fired. As a result, the patterns of voting in rural areas, especially in places where mergers occurred, have become less stable and predictable. Thus, it is not surprising that voting decisions of Japanese voters, particularly those in areas that underwent mergers, have become more susceptible to the popularity of the prime minister and his party.

Specifically, in 2010 and 2012, the LDP was the largest opposition party, because of their historic defeat in the 2009 lower house election. Fortunately for the LDP, the severely unpopular DPJ and their leaders (i.e., then prime ministers) as well as continued macroeconomic problems made voters vote against the DPJ. In 2013, the LDP, as the ruling party, won a landslide victory again in the upper house. This also makes sense given Prime Minister Abe's popularity and the improvement in some of the important economic indicators since he took office in December 2012.

In sum, after the period of drastic municipal mergers, we argue that a ruling party's popularity has become conditional on its performance and effective appeals to unorganized voters, and the LDP's victory does not mean that it rebuilt strong support bases in the countryside. Any mishandling of the economy or any suboptimal response to unexpected shocks (e.g., the 2011 Tohoku tsunami and disasters) could bring down a prime minister's or a ruling party's popularity. 
We believe that this increased uncertainty and unpredictability in election outcomes is a "downstream" effect of the municipal mergers that took place in the early 2000 s. As we explained above, statistically estimating the downstream effect is difficult. There are a number of postmerger mediation variables that have contributed to this volatile pattern of election results. Further theoretical and empirical inquiries identifying a chain of causal effects are left for future research.

\section{Notes}

Earlier versions and components of this article were presented at the 2008 and 2009 annual meetings of the American Political Science Association, and at workshops and seminars at Kansai University, Yale University, Gakushuin University, Kyoto University, and the University of Southern California. We thank Mark Franklin, Kentaro Fukumoto, Steven Reed, Alberto Simpser, and other participants in these conferences, workshops, and seminars for useful comments, and Adam Muller and Edwin Yung for editorial help. This article was finalized before the lower house election held on December 14, 2014. In this election, the LDP and Komeito maintained two-thirds of the seats in the lower house. Our arguments in the Appendix, however, are not affected by the results.

1. The 2007 upper house election was the first national election after the process of mergers was completed in most municipalities. In a later section, we provide a methodological justification for our focus.

2. Also see Horiuchi, Saito, and Yamada (2009) and Rosenbluth, Saito, and Yamada (2011).

3. Following the completion of municipal mergers, the LDP dramatically lost seats in the 2007 upper house election and the 2009 lower house election. They, however, won in two recent national elections - the 2012 lower house election and the 2013 upper house election. In the Appendix we discuss whether and how our results are relevant to the LDP's recent landslide victories.

4. The upper house elections are held every three years, mostly in June or July, while nationwide subnational elections are held every four years in April. Therefore, every twelve years (in the Year of the Boar on the Chinese zodiac), an upper house election follows subnational elections by about three months. Ishikawa (1995) argues that upper house voter turnout drops because subnational politicians have exhausted their resources and have lost the incentive for further mobilization by the time upper house elections take place.

5. Japan's prefectural and municipal governments spend about 60 percent of total government expenditures, but they collect only about 30 percent of the tax revenues (Sōmushō 2008).

6. The underlying assumption is that there are 8,000 eligible voters and the turnout rate is 85 percent. If there are eighteen seats, a candidate can secure a seat by obtaining 358 votes. 
7. Typically, elementary school districts and village clusters informally demarcate the boundaries of a candidate's turf, and these school districts usually correspond with premerger municipal borders set up before the early 1950s. Hubs of local economic and social activities, like post offices, agricultural cooperative branches, nursing homes, child care facilities, and so on, are also located accordingly.

8. These clientelistic transactions are a hotbed of corruption, and there have been a significant number of municipal politicians who were prosecuted for illegal monetary transactions. When a corruption scandal led to the arrest of a city assembly member in Nagoya, the prosecutor confiscated a long list of favors recorded by city officials. See "Shigi kuchikiki ichiranhyō: Jinji yōbō gutaitekini" [Lists of interventions by a city assembly member: promotion, recruitment, and other particular favors], Asahi Shim-bun, December 2, 2003. Also see Fukumoto and Horiuchi (2011) on how the electoral system used in municipal assembly elections gives incentives to candidates and voters to engage in electoral fraud.

9. In Japan, there have been three surges of municipal consolidation movements in modern history, initiated in 1888, 1953, and 1999.

10. Analyses using the actual assembly size for each municipality for the pre- and postmerger periods are left for future works.

11. Asahi Shimbun, January 1, 2003.

12. Asahi Shimbun, Ehime edition, June 20, 2004.

13. To mitigate opposition to mergers from municipal assembly members, there was a special measure in which a merged municipality could choose to allow its members of premerger assemblies to stay in office for an additional two years until the next municipal election. We assume, however, that many of those assembly members, who were able to stay in office only for a short term after the merger, did not have strong incentives to campaign for the LDP even when the 2007 upper house election was held before their own postmerger municipal election. Since those who served the premerger assemblies would have faced a substantially smaller chance of getting reelected in the postmerger municipalities, they would have little incentive to campaign for the LDP for the sake of their own reelections.

14. In a 2012 survey conducted in eighty-nine locations corresponding with premerger rural municipalities, 45 percent of respondents in merged municipalities report that they frequently or somewhat frequently interacted with municipal assembly members ten years ago, while 22 percent still frequently or somewhat frequently interact today. In contrast, the percentage decreased only marginally and insignificantly (specifically, from 35 percent to 34 percent) for the respondents in the municipalities that did not merge (Yamada 2013). Similarly, 74 percent of the respondents in the merged municipalities reported that they now rarely interact or do not interact at all with municipal assembly members, whereas this percentage for the respondents in the intact municipalities is still low at 37 percent (Yamada 2013).

15. As of fiscal year 2001, the mean monthly stipend was JPY 444,700 (about US\$4,000) for city assembly members and JPY 217,300 (about 
US $\$ 2,000$ ) for town and village assembly members (Asahi Shimbun, January $1,2003)$. Since serving in the municipal legislature is a part-time job in nature, these positions represent a good supplementary income source, especially for those who reside in rural areas.

16. After this election, two lower house elections were held in 2009 and 2012, and two more upper house elections were held in 2010 and 2013. In the Appendix, we discuss the methodological difficulty of estimating such longer-term consequences.

17. Since municipalities' population sizes differ widely, we weighted each observation by the number of eligible voters in the 2007 upper house election. The data sources are Yomiuri Shimbun (2001) and Asahi Shimbun (2007). The votes for governing parties include candidates from the LDP and its coalition partner New Komeito, together with candidates from other satellite parties (e.g., Conservative Party in 2001). Independents backed by local LDP branch organizations are also coded as governing party candidates.

18. Cities designated by ordinance (seirei shitei toshi) have smaller administrative units (wards), but all variables used in our analysis are measured and/or aggregated at the city level. Some variables are missing for the village of Miyake, which is thus dropped from analysis, because all the residents were forced to evacuate to other municipalities due to a major volcanic eruption while the 2000 census data were collected.

19. The proportion of eligible voters residing in the new municipalities is 38 percent.

20. Changing the base year of comparison (i.e., using 2004 upper house elections instead of 2001) does not substantially change our findings. Results are available upon request from the authors.

21. Analyzing the governing parties' vote share in the PR portion also yields similar results.

22. In our regression analysis, we only include one of these three main independent variables to avoid problems of high multicollinearity.

23. For all of these demographic variables, we also inspected to see if our analysis is affected by using the level variables from the 2005 census instead of the difference between the 2005 and the 2000 censuses. The effects of our independent variables do not change substantially and thus do not change our conclusion.

24. A more commonly used proxy for urbanness is the proportion of residents in densely inhabited districts (DIDs) within each municipality. We prefer to use a change in the population size (in log), because it does not have lower and upper limits. If the DID ratio is already close to 100 percent (such as in most municipalities in Tokyo and Osaka), the DID ratio does not change even when people migrate to those highly urban municipalities. An alternative is to use a change in the (raw) number of residents in DIDs within each municipality. This variable, however, is not necessarily a valid proxy for urbanization (or depopulation) because it does not change for a rural municipality if people who left the municipality are not from DIDs. Note that other demographic variables we use, which we introduce shortly, are in percentage- 
point difference (in log). These variables also have upper and lower limits. As only a small proportion of municipalities are close to 100 percent or 0 percent for each of these variables, however, each differenced variable exhibits a reasonable variation across municipalities.

25 . The data source of intergovernmental transfers and fiscal-yearend municipal populations are from Chihō Zaisei Chōsa Kenkyū Kai $(2002,2008)$. As with the four demographic variables, we also checked to see if our estimates would be affected by using the level variable from the fiscal year 2006 data. The estimated coefficients of the main independent variables do not change (i.e., all are negative), and they are statistically significant regardless of whether we use the change or the level of this variable.

26. Municipalities with smaller population size receive a larger amount of formulaically allocated grant-in-aid on the per capita basis. Consequently, a merger almost always results in a decrease in the per capita transfer to the municipality. To mitigate drastic reductions, for ten years following mergers, merged municipalities were allowed to receive formulaically allocated grantin-aid equal to the total amount that premerger municipalities would have received if they had remained intact.

\section{References}

Asahi Shimbun. 2007. Asahi.com de miru 2007 Saninsen no subete [Everything about the 2007 House of Councillors elections as seen in Asahi.com]. Tokyo: Asahi Shimbunsha.

Asano, Masahiko. 1998. "Kokusei senkyo ni okeru chihō seijika no senkyo dōin: Idoshi genshō no nazo" [Do local politicians' mobilization efforts matter in national elections?]. Senkyo kenkyu [Japanese journal of electoral studies] 13: 120-129.

Chihō Zaisei Chōsa Kenkyū Kai [Study Group on Local Government Finance]. 2002. Shichōson betsu kessan jōkyō shirabe, heisei 12-nen ban [Report on municipality financial statements, fiscal year 2000]. Tokyo: Chihō Zaisei Chōsa Kenkyū Kai.

- 2008. Shichōson betsu kessan jōkyō shirabe, heisei 18-nen ban [Report on municipality financial statements, fiscal year 2006]. Tokyo: Chihō Zaisei Chōsa Kenkyū Kai.

Curtis, Gerald L. 1992. "Japan." In Electioneering: A Comparative Study of Continuity and Change, ed. D. Butler and A. Ranney, 222-243. Oxford: Clarendon Press.

Dahl, Robert A., and Edward R. Tufte. 1973. Size and Democracy. Stanford: Stanford University Press.

Fenno, Richard F. 1978. Home Style: House Members in Their Districts. Boston: Little, Brown.

Fukui, Haruhiro, and Shigeko N. Fukai. 1996. "Pork Barrel Politics, Networks, and Local Economic Development in Contemporary Japan." Asian Survey 36, 3: 268-286. 
Fukumoto, Kentaro, and Yusaku Horiuchi. 2011. "Making Outsiders' Votes Count: Detecting Electoral Fraud Through a Natural Experiment." American Political Science Review 105, 3: 586-603.

Gaines, Brian J. 1999. "Duverger's Law and the Meaning of Canadian Exceptionalism." Comparative Political Studies 32, 7: 835-861.

Horiuchi, Yusaku. 2005. Institutions, Incentives and Electoral Participation in Japan: Cross-Level and Cross-National Perspectives. London: Routledge Curzon.

Horiuchi, Yusaku, and Jun Saito. 2003. "Reapportionment and Redistribution: Consequences of Electoral Reform in Japan." American Journal of Political Science 47, 4: 669-682.

Horiuchi, Yusaku, Jun Saito, and Kyohei Yamada. 2009. "Politics of Municipal Mergers in Japan: The Electoral Resource Allocation of the Dominant Party." Paper presented at the annual meeting of the American Political Science Association, Toronto, September 3-6.

Imai, Kosuke, Luke Keele, Dustin Tingley, and Teppei Yamamoto. 2011. "Unpacking the Black Box of Causality: Learning About Causal Mechanisms from Experimental and Observational Studies." American Political Science Review 105, 4: 765-789.

Imai, Ryosuke, and Ikuo Kabashima. 2007. "Naze Jiminto wa ichininku de zanpai shita noka" [Why the LDP suffered a landslide defeat in singlemember districts]. Chuō kōron October: 190-199.

Ishikawa, Masumi. 1995. Sengo seijishi [Postwar political history]. Tokyo: Iwanami.

1999. Ochiteiku seiji [Corrupting politics]. Tokyo: Iwanami.

Jiyū Minshutō Gyōsei Kaikaku Suishin Honbu [Administrative Reform Task Force of the Liberal Democratic Party]. 1998. Shichōson gappeitō nitsuite no kangaekata [Guidelines for municipal mergers]. Tokyo: Jiyū Minshutō.

Jones, Mark P. 1997. "Federalism and the Number of Parties in Argentine Congressional Elections." Journal of Politics 59, 2: 538-549.

McElwain, Kenneth M. 2012. "The Nationalization of Japanese Elections." Journal of East Asian Studies 12: 323-350.

Myerson, Roger B. 1993. "Incentives to Cultivate Favored Minorities Under Alternative Electoral Systems." American Political Science Review 87, 4: 856-869.

Nichter, Simeon. 2008. "Vote Buying or Turnout Buying? Machine Politics and the Secret Ballot." American Political Science Review 102, 1: $19-32$.

Persson, Torsten, and Guido E. Tabellini. 2002. Political Economics: Explaining Economic Policy. Cambridge: MIT Press.

Reed, Steven R., Ethan Scheiner, and Michael F. Thies. 2012. "The End of LDP Dominance and the Rise of Party-Oriented Politics in Japan." The Journal of Japanese Studies 38, 2: 353-376.

Rosenbaum, Paul R. 1984. "The Consequences of Adjustment for a Concomitant Variable That Has Been Affected by the Treatment." Journal of the Royal Statistical Society: Series A (General): 656-666. 
Rosenbluth, Frances M., Jun Saito, and Kyohei Yamada. 2011. "Electoral Adaptation in Japan: Party Strategy After Electoral Rule Change." The Journal of Social Science 62, 1: 5-23.

Rosenstone, Steven J., and John M. Hansen. 1993. Mobilization, Participation, and Democracy in America. New York: Macmillan.

Samuels, D. 2000. "The Gubernatorial Coattails Effect: Federalism and Congressional Elections in Brazil." Journal of Politics 62, 1: 240-253.

Sasaki, Nobuo. 2004. Chihō ha kawareruka [Can local governments change?]. Tokyo: Chikuma Shobō.

Scheiner, Ethan. 2005. Democracy Without Competition in Japan: Opposition Failure in a One-Party Dominant State. New York: Cambridge University Press.

Shimizu, Kay. 2012. "Electoral Consequences of Municipal Mergers." Journal of East Asian Studies 12, 3: 381-408.

Soga, Kengo, and Satoshi Machidori. 2007. Nihon no chihō seiji: Nigen daihyōsei seifu no seisaku sentaku [Local politics in Japan: Policy choices in presidential systems]. 1st ed. Nagoya: Nagoya Daigaku Shuppankai.

Sōmushō [Ministry of Internal Affairs and Communications]. 2008. Chihō zaisei hakusho [White paper on local government finance]. Tokyo: Sōmushō.

Sōmushō Jichi Gyōseikyoku Senkyobu [Ministry of Internal Affairs and Communications Local Autonomy Bureau]. 2007. Chihō kōkyō dantai no gikai no giin oyobi chō no shozoku tōhabetsu jinin sirabe nado [Partisan affiliation of municipal assembly members and municipal mayors]. Tokyo: Ministry of Internal Affairs and Communication.

Sōmushō Tōkeikyoku [Ministry of Internal Affairs and Communications, Statistics Bureau]. 2002. Heisei 12-nen kokusei chōsa [National census 2000]. Tokyo: Nihon Tōkei Kyōkai.

- 2007. Heisei 17-nen kokusei chōsa [National census 2005]. Tokyo: Nihon Tōkei Kyōkai.

Stokes, Susan C. 2005. "Perverse Accountability: A Formal Model of Machine Politics with Evidence from Argentina." American Political Science Review 99, 3: 315-325.

Weese, Eric. 2012. "Political Mergers as Coalition Formation: An Analysis of the Heisei Municipal Amalgamations." Paper presented at the Georg Walter Leitner Program in International and Comparative Political Economy seminar series, Yale University.

Yamada, Kyohei. 2013. "Causes and Consequences of Municipal Mergers in Japan.” PhD diss., Yale University.

Yokomichi, Kiyotaka. 2007. "The Development of Municipal Mergers in Japan." Up-to-date Documents on Local Autonomy in Japan No. 1. Council of Local Authorities for International Relations (CLAIR), Institute for Comparative Studies in Local Governance (COSLOG), National Graduate Institute for Policy Studies (GRIPS).

Yomiuri Shimbun. 2001. Saninsen 2001 deta CD-ROM [Data CD-ROM for the 2001 House of Councillors election]. Tokyo: Yomiuri Shimbun. 


\title{
LYNNE RIENNER PUBLISHERS
}

\section{Northeast Asia's Nuclear Challenges}

\author{
Su Hoon Lee, editor
}

$\mathrm{A}_{\text {peace and security of Northeast }}$ Asia, not least how to contain a nuclear North Korea and ensure the safety of the region's nuclear power structure. Addressing multiple dimensions of these

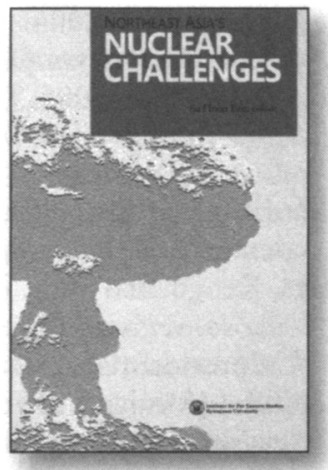
crucial issues, the authors of Northeast Asia's Nuclear Challenges highlight the cooperative approaches needed not only among the primary actors - China, the two Koreas, Russia, and the United States-but throughout the international community.

Contents: Introduction: A Myriad of Challenges-Carving a Peaceful, Stable, and Secure Northeast Asia-S.H. Lee. An Assessment of the Obama Doctrine-L. Sigal. Global Partnerships Against the Spread of Weapons and Materials of Mass Destruction: A Russian Perspective-A.G. Savelyev. Reassessing the G-8 Global Partnership: A South Korean Perspective-S.H. Lee. Addressing the North Korean Nuclear Threat: A Strategic-Pragmatic Comprehensive Perspective and Its Policy Alternatives-K.Y. Park. Can the North Korean Nuclear Crisis Be Resolved?-S.S. Hecker. Nuclear Power in China, Japan, and Korea: A Current and Future Assessment-J. Cai. Overcoming the Cold War Mindset: A Case for Promoting a Nuclear-Weapons Convention and a Nuclear-Weapon-Free Zone-T. Takahara.

2013/229 pages - pb $\$ 24.95$

No rights in North or South Korea

Explorations in Korean Studies

Distributed for the Institute for Far Eastern Studies, Kyungnam University 